\title{
Preparation of Ni-Ti Shape Memory Alloy by Spark Plasma Sintering Method
}

Pavel Salvetrr ${ }^{1}$, Tomáš František Kubatík ${ }^{2}$, Pavel Novák ${ }^{1}$

${ }^{1}$ University of Chemistry and Technology, Department of Metals and Corrosion Engineering, Technicka 5, 16628 Prague 6, Czech Republic

${ }^{2}$ Institute of Plasma Physics ASCR, v.v.i., Za Slovankou 1782/3, 18200 Prague 8, Czech Republic

Email: salvetrp@vscht.cz, kubatik@ipp.cas.cz,panovak@vscht.cz

This paper aims to describe powder metallurgy methods of production Ni-Ti shape memory alloy - self-propagating high-temperature synthesis (SHS) and spark plasma sintering (SPS). There are compared microstructures and phase compositions of alloys produced by SHS and by a technology containing SHS, milling and SPS. At the same time there is determined the influence of the SPS sintering temperature on the structure of Ni-Ti alloy. Self-propagating high-temperature synthesis was initiated at $1100^{\circ} \mathrm{C}$ with process duration 20 minutes the heating rate of approx. $300^{\circ} \mathrm{C} / \mathrm{min}$. The product is highly porous and contains undesirable $\mathrm{Ti}_{2} \mathrm{Ni}$ phase. The SPS technique allows to obtain product with low porosity. The disadvantages of SPS technique are growing amount of $\mathrm{Ti}_{2} \mathrm{Ni}$ phase and formation of other undesirable phases $\left(\mathrm{Ni}_{4} \mathrm{Ti}_{3}\right.$ and $\left.\mathrm{Ni}_{3} \mathrm{Ti}\right)$.

Keywords: powder metallurgy, reactive sintering, spark plasma sintering, Ni-Ti alloy

\section{Acknowledgement}

This research was financially supported by Czech Science Foundation, project No. 14-03044S.

\section{References}

[1] ÖLANDER, A. (1932). An electrochemical investigation of solid cadmium-gold alloys. Journal of the American Chemical Society, Vol. 54, pp. 3819-3833.

[2] MOHD JANI, J., LEARY, M., SUBIC, A., GIBSON, M. A. (2014). A review of shape memory alloy research, applications and opportunities, Materials \& Design, Vol. 56, pp. 1078-1113.

[3] BUEHLER, W. J., GILFRICH, J. V., WILEY, R. C. (1963). Effect of Low-Temperature Phase Changes on the Mechanical Properties of Alloys near Composition TiNi. Journal of Applied Physics, Vol. 34, pp. 1475-1477.

[4] A Historical Perspective. Nitinol Devices \& Components, Inc.. http://www.nitinol.com/nu-category/nitinol-thebook (accessed Jan 11, 2016).

[5] Other Alloys Exhibiting Shape Memory Effects. Nitinol Devices \& Components, Inc.. http://www.nitinol.com/nucategory/nitinol-the-book (accessed Jan 11, 2016).

[6] OTSUKA, K., REN, X. (2005). Physical metallurgy of Ti-Ni-based shape memory alloys, Progress in Materials Science, Vol. 50, pp. 511-678.

[7] NAYAN, N., GOVIND, SAIKRISHNA, C.N., RAMAIAH, K.V., BHAUMIK, S.K., NAIR, K.S., MITTAL, M.C. (2007). Vacuum induction melting of NiTi shape memory alloys in graphite crucible, Materials Science and Engineering: $A$, Vol. 465, pp. 44-48.

[8] FRENZEL, J., ZHANG, Z., NEUKING, K., EGGELER, G. (2004). High quality vacuum induction melting of small quantities of NiTi shape memory alloys in graphite crucibles, Journal of Alloys and Compounds, Vol. 385 , pp. 214-223.

[9] FOROOZMEHR, A., KERMANPUR, A., ASHRAFIZADEH, F., KABIRI, Y. (2011). Investigating microstructural evolution during homogenization of the equiatomic NiTi shape memory alloy produced by vacuum arc remelting, Materials Science and Engineering: A, Vol. 528, pp. 7952-7955.

[10] ELAHINIA, M.H., HASHEMI, M., TABESH, M., BHADURI, S.B. (2012). Manufacturing and processing of NiTi implants: A review, Progress in Materials Science, Vol. 57, pp. 911-946.

[11] DUERIG, T., PELTON, A., TREPANIER, CH. (2011). Nitinol - PART I Mechanism and Behaviour, SMST eElastic newsletter, ASM International.

[12] KAIEDA, Y. (2003). Fabrication of composition-controlled TiNi shape memory wire using combustion synthesis process and the influence of $\mathrm{Ni}$ content on phase transformation behavior, Science and Technology of Advanced Materials, Vol. 4, pp. 239-246. 
[13] NOVÁK, P., KŘÍŽ, J., MICHALCOVÁ, A., SALVETR, P. (2015). Role of Reactive Sintering in Production of Technically Important Intermetallics, Manufacturing Technology, Vol. 15, pp. 74-77.

[14] NOVÁK, P., MICHALCOVÁ, A., ŠERÁK, J., VOJTĚCH, D., FABIÁN, T., RANDÁKOVÁ, S., PRŮŠA, F., KNOTEK, V., NOVÁK, M. (2009). Preparation of Ti-Al-Si alloys by reactive sintering, Journal of Alloys and Compounds, Vol. 470, pp. 123-126.

[15] WISUTMETHANGOON, S., DENMUD, N., SIKONG, L. (2009). Characteristics and compressive properties of porous NiTi alloy synthesized by SHS technique, Materials Science and Engineering: A, Vol. 515, pp. 93-97.

[16] NOVÁK, P., MEJZLÍKOVÁ, L., MICHALCOVÁ, A., ČAPEK, J., BERAN, P., VOJTĚCH, D. (2013). Effect of SHS conditions on microstructure of NiTi shape memory alloy, Intermetallics, Vol. 42, pp. 85-91.

[17] SALVETR, P., MORAVEC, H., NOVÁK, P. (2015). Ni-Ti Alloys Produced by Powder Metallurgy, Manufacturing Technology, Vol. 15, pp. 689-694.

[18] CHU, C. L., CHUNG, C. Y., LIN, P. H., WANG, S. D. (2004). Fabrication of porous NiTi shape memory alloy for hard tissue implants by combustion synthesis, Materials Science and Engineering: A, Vol. 366, pp. 114-119.

[19] NOVÁK, P., MORAVEC, H., SALVETR, P., PRŮŠA, F., DRAHOKOUPIL, J., KOPEČEK, J., KARLÍK, M., KUBATÍK, T. F. Preparation of nitinol by non-conventional powder metallurgy techniques, Materials Science and Technology, DOI: 10.1179/1743284715Y.0000000041.

[20] CHEN, G., LISS, K. D., CAO, P. (2014). In situ observation and neutron diffraction of NiTi powder sintering, Acta Materialia, Vol. 67, pp. 32-44. 